\title{
Decay rate of Larix gmelinii coarse woody debris on burned patches in the Greater Khingan Mountains
}

\author{
Shubo Huang ${ }^{1}$ Lixiang Wen ${ }^{1}$ Shuai Yin ${ }^{2}$. \\ Meng Guo ${ }^{1} \cdot$ Fangbing Yu ${ }^{1}$
}

Received: 2 August 2020 / Accepted: 27 October 2020 / Published online: 5 December 2020

(C) The Author(s) 2020

\begin{abstract}
The decomposition of coarse woody debris (CWD) affects the energy flow and nutrient cycling in forest ecosystems. Previous studies on CWD have focused on the input, decomposition, reserve dynamics, and CWD functions, but coarse woody debris decomposition is complex and the results from different regions vary considerably. It is not clear which factors affect decay rate $(k)$, especially at different decomposition stages. In this study, a singleexponential decay model was used to analyze the characteristics of CWD decomposition in Larix gmelinii forests over the 33 years following a fire in the Greater Khingan Mountains. The results show that the decay rate of coarse woody debris was positively correlated to decay class. The average decomposition rate was 0.019 , and 41 years and 176 years are needed for a $50 \%$ and $95 \%$ mass loss, respectively. CWD nutrient content, density, and water content could explain the variance in the decay rate $(\sim 42 \%)$ of the decay factors such as amount of leaching, degree of fragmentation, respiration
\end{abstract}

Project funding: This research was funded by the National Key Research and Development Projects, Grant Number 2018 YFE0207800 and the National Natural Science Foundation of China, Grant Number 41871103.

The online version is available at http://www.springerlink.com.

Corresponding editor: Yu Lei

Meng Guo

guom521@nenu.edu.cn

1 Key Laboratory of Geographical Processes and Ecological Security in Changbai Mountains, School of Geographical Sciences, Northeast Normal University, Ministry of Education, Changchun 130024, People's Republic of China

2 Center for Global Environmental Research, National Institute for Environmental Studies, Tsukuba 3058506, Japan of the debris, and biotransformation, and varied significantly between different decay classes. Using the spacetime substitution method, this study arranged the coarse woody debris of different mortality times to form a 33 year chronosequence which revealed the decomposition process. It was concluded that the decay rate was mainly explained by structural component of the debris and its nitrogen and water contents. This paper quantifies the indicators affecting CWD decay to explain the decomposition process.

Keywords Coarse woody debris $\cdot$ Decay rate $\cdot$ Spacetime substitution $\cdot$ Boreal forest $\cdot$ Fire disturbance

\section{Introduction}

Coarse woody debris (CWD) in the form of snags, downed boles or large branches is an important structural and functional component of forest ecosystems (Harmon et al. 1986). CWD affects biotic and abiotic processes through physical and biological effects and plays an important role in longterm nutrient storage and tree regeneration (Wu et al. 2005). It also provides habitats for various organisms and maintains environmental heterogeneity, biodiversity, and the integrity of ecosystems. In particular, habitat provision and nutrient storage are significant for maintaining the continuity of biodiversity and biogeochemical processes (Sturtevant et al. 1997). Research has combined the characteristics of coarse woody debris with forest succession (Carmona et al. 2002), community composition (Motta et al. 2006), nutrient cycles (Currie and Nadelhoffer 2002), and forest management (Montes and Cañellas 2006) to study its function and decomposition in forest ecosystems. Coarse woody debris accounts for approximately $5 \%$ of carbon (C) storage in terrestrial ecosystems, and in forest ecosystems, for $2-10 \%$ of 
above-ground biomass (Delaney et al. 1998). The proportion of above-ground biomass represented by CWD depends largely on geographical location, forest management practices, disturbances and successional stage. Coarse woody debris biomass in natural forests and plantations usually differs. CWD reserves of old forests with little human disturbance can be up to 100 times higher than that in young forests (Carmona et al. 2002). Furthermore, the relative contribution of woody debris to ecosystem C storage increases with increasing stand age (Zhu et al. 2017).

CWD decomposition is a complex process, integrating respiration, biological transformation, leaching, fragmentation, collapse, settling, and weathering under the influence of physical, chemical and biological (especially microbial) processes. It is one of the main ways in which $\mathrm{C}$ fixed during photosynthesis is returned to the atmosphere or converted to soil organic C. Decomposition is driven by heterotrophic respiration of decomposers and directly emits $\mathrm{CO}_{2}$ into the atmosphere (Mackensen et al. 2003). Dynamic changes in CWD depend on the differences between income and loss (Olson 1963), where income is caused by the natural death of trees or disturbance, and loss is the decomposition of woody debris. The decay class can qualitatively describe the degree of decomposition, expressed by external morphological characteristics, and quantitatively measure decomposition speed via the decay rate, expressed by the decay constant $k$ (Laiho and Prescott 1999; Kruys et al. 2002). The decay rate of CWD is slow and variable and influenced by species, temperature, humidity, material quality, size, and decay class. Since water content in wood is the basic environment of fungal growth, it is considered as the most important factor in CWD decomposition (Harmon et al. 1986). Moreover, angiosperms have more complex vascular structures than gymnosperms, but the latter have slower rates of decomposition because of lower $\mathrm{N}$ contents and higher $\mathrm{C} / \mathrm{N}$ ratios. The relationship between the structural components and decay rate of gymnosperms is insignificant, and low $\mathrm{N}$ and high lignin contents are closely related to rate of gymnosperm decay (Weedon et al. 2008; Zhang and Wang 2010). The role of coarse woody debris in nutrient cycling of forest ecosystems is generally poorly understood, and the importance of CWD to forest productivity remains controversial (Spies et al. 1988).

Some researchers have emphasized the importance of the decomposition mechanism (fragmentation, respiration, and leaching), and considered the degree of sample fragmentation in terms of mass loss. Various models for calculating the decay constant have been proposed (Sollins 1982; Marra and Edmonds 1994). CWD decay exponential models include single-exponential, double-exponential, multiple-exponential, and lag-time models, where the first three consider only respiration and leaching, and the latter consider fragmentation. The differences in decay rates in CWD calculated in current studies reflect variations in the fore mentioned calculation methods and in ecosystems (Attiwill 1994). Single-exponential models are widely used and assume that the decay rate is constant and CWD is homogeneous. However, decay rates vary throughout the decomposition process and depend on the climate, species, size of material, decay class, slope position, aspect, and site conditions. The decomposition process may be divided into several stages and each stage described by a different single-exponential model (Yatskov et al. 2003). This process can also be modeled based on physiological assumptions or matrix models (Kruys et al. 2002). Numerous studies have used $50 \%$ and $95 \%$ of the coarse woody debris mass loss time to represent CWD turnover, and the decay rate of boreal forest species was 0.003-0.071 with a mean value of 0.02 . The $95 \%$ mass loss, calculated according to the mean value, was about 150 years (Laiho and Prescott 1999). The decay rate of different tree species is very different. Xu (1988) calculated the average decomposition rate of Larix gmelinii (Rupr.) Rupr CWD to be 0.013 . The decay rate of Tilia amurensis, a common species in the Lesser Khingan and Changbai mountains is 0.028 , and for Pinus koraiensis Sieb, it is 0.016 . The decay rate of Tsuga heterophylla (Raf.) Sarg., widely distributed in the western Pacific Coast of the United States, is 0.016-0.019, and for Pseudotsuga menziesii, it is 0.005-0.010 (Chen and Harmon 1992). It indicates that the decay rate of Larix gmelinii is much lower than that of Tilia amurensis, Pinus koraiensis and Tsuga heterophylla, slightly higher than that of Pseudotsuga menziesii. In the Greater Khingan Mountains, the species with the slowest decay rate is Larix gmelinii and the fastest is Betula platyphylla Suk., and the rate for Pinus sylvestris is between the two species (Xu 1988).

Fire changes the succession process in forest ecosystems, affecting energy flows, nutrient cycles, and information transfer between various components. Fires also play an important role in maintaining and improving the age distribution as well as maintaining biodiversity and stability. A large amount of CWD is created after a fire, some is generated immediately and some after a few years. In addition to disturbances such as fire, a certain amount is generated during succession (Amiro et al. 2006). Forests in northern China account for $14.5 \%$ of the world's land area. From 1950 to 2014, 806,000 forest fires occurred cumulatively (12,400 annually), and 38.093 million ha of forested area (586,000 ha per year) was affected (Lierop et al. 2015). Every year, 5-20 million ha of China's northern forest is burned, releasing about $1.82 \times 1011 \mathrm{~kg}$ of $\mathrm{C}$ and accounting for $9.1 \%$ of global $\mathrm{C}$ emissions from fires. Most studies focus on this stage of a forest fire, i.e., on post-fire ecological and environmental impacts on vegetation and on habitat restoration, and the adaptation characteristics of organisms to fire (McLauchlan et al. 2020). Numerous studies have 
used dynamic vegetation simulation models to re-create the effects of fires on carbon cycling. Forest fires can reduce the C sink capacity of ecosystems but the extent of such impacts remains uncertain (Hayes et al. 2011; Yue et al. 2015). In addition, accurate prediction of tree mortality is crucial for adaptive forest management and estimation of wood debris input after fire. Fernandes et al. (2008) reviewed forest fire mortality models of seven European coniferous forests and found that the resistance of pines to low- to moderate-intensity fire arose from adaptive traits that keep the tree alive; fire-sensitive species can also tolerate low-intensity fires. Catry et al. $(2010,2013)$ studied post-fire mortality rate of mixed forests in central Portugal and found that mortality rates in conifers were as high as $90 \%$ four years after a fire. More than $75 \%$ of broad-leaved crowns were mortally damaged whereas the mortality rate of regenerated broad-leaved trees through germination was only $8 \%$. The post-fire mortality rate of conifers was controlled by fire intensity, and that of broad-leaved crowns decreased with increasing bark thickness and diameter.

To reveal the mechanism of short- term CWD decomposition, researchers replaced long-term repeated measurements with a space-time substitution method which provided indirect information on decay rate (Harmon et al. 1986; Tyrrell and Crow 1994; Frangi et al. 1997; Lorimer 2011). This study assumed that the time of death of CWD was the year of the burn. Based on a space-time substitution method, it was hypothesized that all the burned patches had similar site conditions, including altitude, slope, aspect and vegetation cover and we want to answer: (1) In the Greater Khingan Mountains, how many years will it take for Larix gmelinii CWD to decompose following a fire? (2) What factors affect the decay rate of CWD; and, (3) How do these factors affect the decay rate of CWD in different decomposition phases.

\section{Materials and methods}

\section{Study region}

The forests of the Greater Khingan Mountains are part of the global cold-temperate forests and a southern extension of the eastern Siberian coniferous forests of Northern Eurasia (Fig. 1). The forest area is $11.2 \%$ of China's total forest area and accounts for more than a third of carbon storage (Wang et al. 2001). The main chain of the Greater Khingan Mountains is NNE-SSW and is steeper in the east than in the west. The northern branch is WNW-ESE, $235 \mathrm{~km}$ long by, $200 \mathrm{~km}$ wide, a total of $8.3 \times 10^{6} \mathrm{~km}^{2}$, with elevations $260-1700 \mathrm{~m}$ a.s.1. (Guo et al. 2020). Larix gmelinii often forms large simple forests, or mixed forests with Betula platyphylla, Pinus sylvestris var.mongolica, Picea asperata, Populus davidiana dode, and other minor species. Soils are brown coniferous forest soil with different soil subclasses under different types of Larch forest (Xu 1988). The climate is a cold temperate continental
Fig. 1 Location of burned patches in study forests in the Greater Khingan Mountains

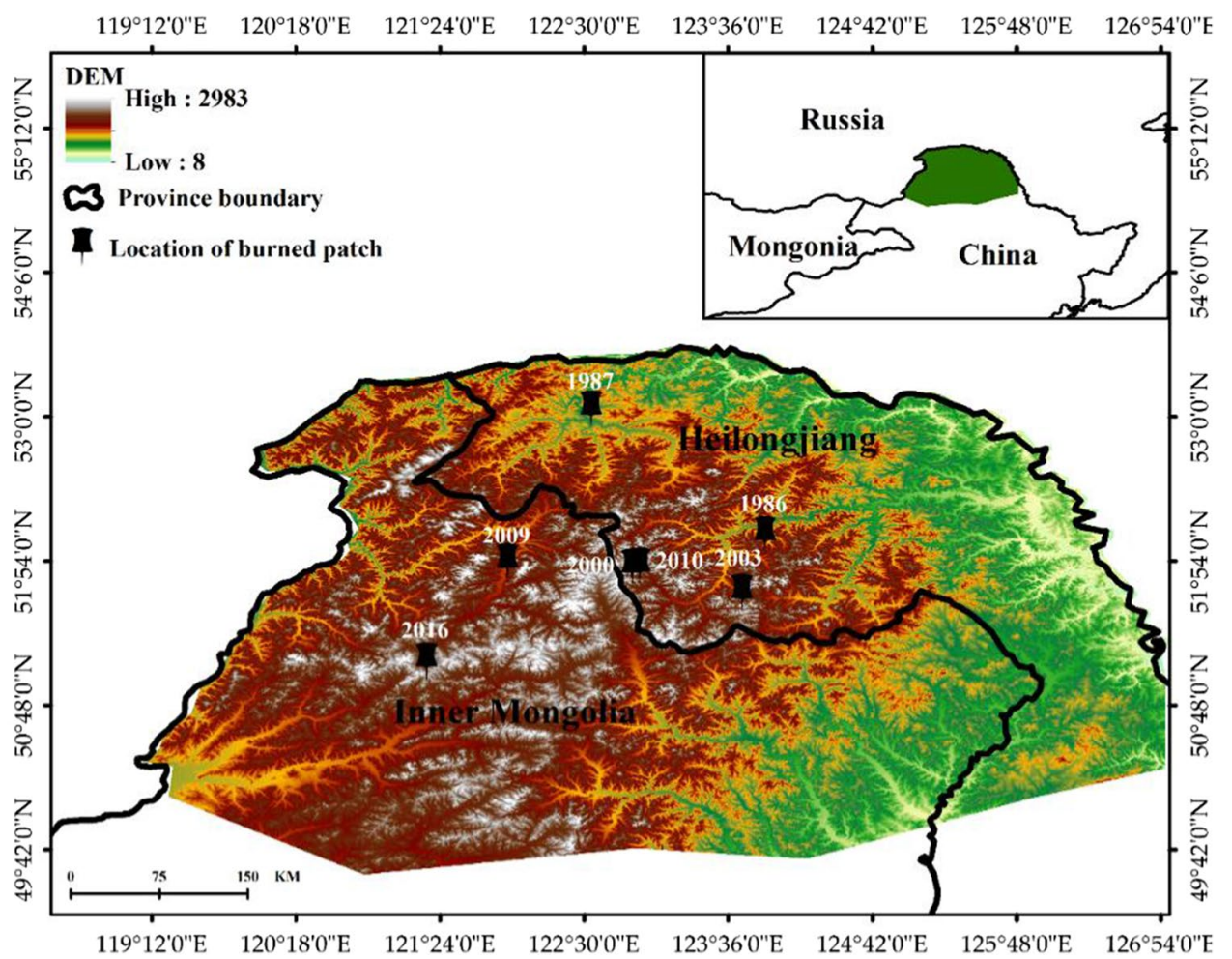


monsoon with an annual average temperature of approximately $-2.8{ }^{\circ} \mathrm{C}$, maximum and minimum temperatures of $35^{\circ} \mathrm{C}$ and $-52{ }^{\circ} \mathrm{C}$, respectively, and an annual average precipitation of $460 \mathrm{~mm}$. The rainy period is from June to September, and a frost-free period lasts 90-110 days (Xu 2018). Winter can extend up to nine months with little precipitation under the control of the Mongolian high pressure system. Summer is brief, preceded by a definite spring and succeeded by a distinct autumn season, all affected by dry winds from Mongolia bringing drastic changes in weather, e.g., high temperatures, low humidities, strong winds, and high forest fire frequency (Hu et al. 2004). The Greater Khingan Mountains area is widely affected by forest fires which are both environmentally beneficial as well as disruptive. The average annual number of fires is over 35 with an average area burned of 76,600 ha (Guo 2007). Fire affects forest soils, hydrology, and biology, which in turn affect the structure, function, and dynamics of individual plants, populations, and communities.

\section{Sample collection and decay classification of Larix gmelinii}

In July 2019, 60 Larix gmelinii samples were collected from seven burned patches (Fig. 1, Table 1) in the study area (Fig. 2). It was assumed that the coarse woody debris developed during the same year as the fire disturbance, and samples of different decay classes were collected according to site conditions. Each $20 \mathrm{~cm}$ bole sample was numbered and taken to the laboratory. The sample indices were unevenly distributed from the outside to inside, each divided into several parts, and three randomly selected to measure the indices separately and then averaged to represent the average condition of each sample.

No uniform standard exists for CWD diameter research purposes (Yuan et al. 2011). Harmon et al. (1986) proposed that debris with diameters $\geq 2.5 \mathrm{~cm}$ qualified as CWD. Other studies have used $\geq 2.5 \mathrm{~cm}$ (Tang et al. 2003; Zhang et al. 2009; Liu et al. 2011), $7.6 \mathrm{~cm}$ (Wu et al. 2011), $8 \mathrm{~cm}$ (Yang et al. 2002b) and $10 \mathrm{~cm}$ (Yuan et al. 2012). CWD in burned patches was dominated by snags and logs. This study considered woody
Table 1 Basic information of burned patches

\begin{tabular}{llrlll}
\hline Burned year & Altitude $(\mathrm{m})$ & Slope $\left(^{\circ}\right)$ & Aspect & Slope position & $\begin{array}{l}\text { Burned } \\
\text { area } \\
\left(\mathrm{km}^{2}\right)\end{array}$ \\
\hline 1986 & 520 & 8.67 & Half shady slope & Middle Slope & 0.59 \\
1987 & 440 & 1.02 & Half shady slope & Flat Slope & 2.07 \\
2000 & 900 & 13.43 & Half sunny slope & Middle Slope & 1.48 \\
2003 & 680 & 0.11 & Half shady slope & Flat Slope & 0.84 \\
2009 & 650 & 4.43 & Half sunny slope & Flat Slope & 0.30 \\
2010 & 850 & 10.91 & Half sunny slope & Middle Slope & 6.35 \\
2016 & 920 & 4.75 & Sunny slope & Flat Slope & 0.17 \\
\hline
\end{tabular}

Qualitative description of slope direction: $315^{\circ}-45^{\circ}$, Shady slope; $90^{\circ}-135^{\circ}$ and $225^{\circ}-270^{\circ}$, Half sunny slope; $135^{\circ}-225^{\circ}$, Sunny slope; $45^{\circ}-90^{\circ}$ and $270^{\circ}-315^{\circ}$, Half shady slope
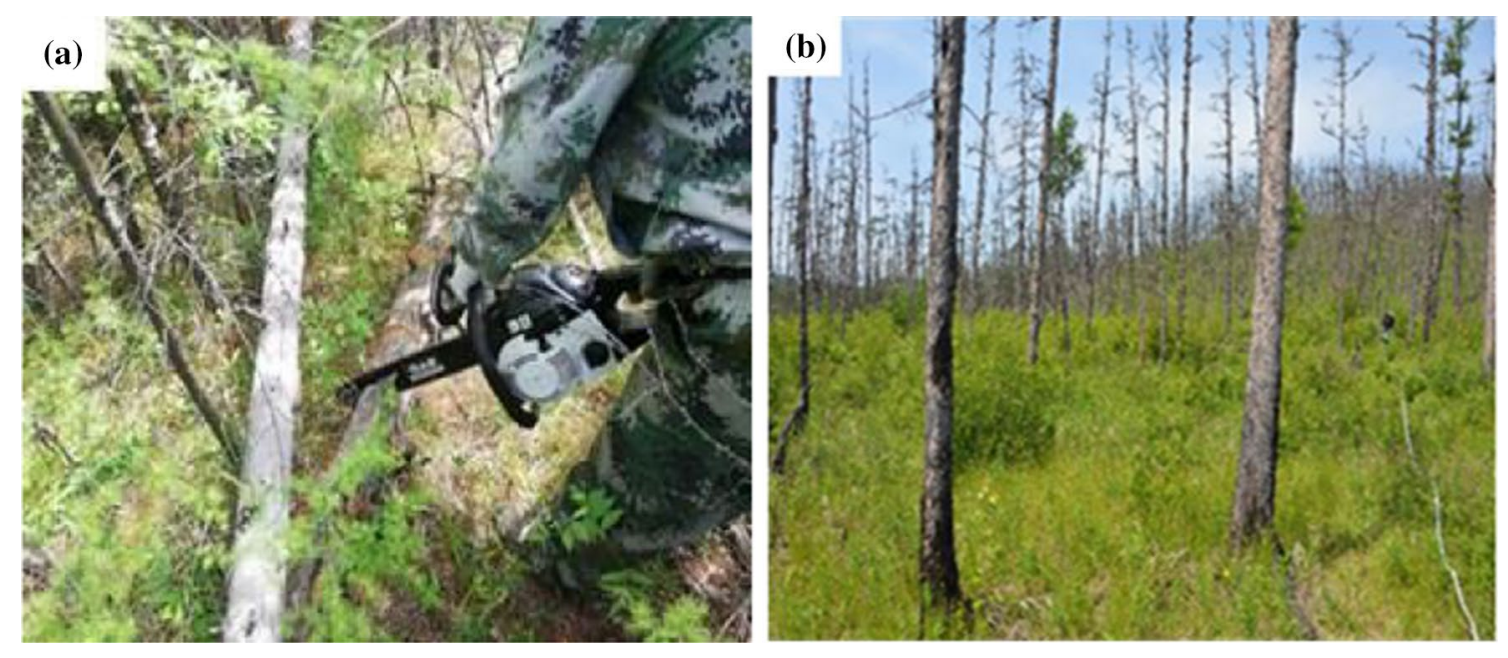

Fig. 2 Burned patches in the Greater Khingan Mountains in 2003 a and 2010 b 
debris with diameters $\geq 7.6 \mathrm{~cm}$ as CWD and further classified it into five standards proposed by Sollins (1982) and Fogel and Cromack (2011), combined with the characteristics of L. gmelinii (Table 2) to render them suitable for boreal forests.

\section{Space-time substitution}

Space-time substitution is a commonly used method for studying vegetation succession and restoration. In forest ecosystems, complete restoration may often take several decades or centuries. To determine the short-term decay rate of CWD, researchers have developed a space-time substitution sampling method (Harmon et al. 1986; Tyrrell and Crow 1994; Frangi et al. 1997; Lorimer 2011). Typically sites at different succession stages are chosen in a region or in different regions with similar environments. The decay rate of CWD at different times varies with changes in its density and represents the actual decomposition dynamics.

In order to calculate the decay rate of CWD, the burn year was determined from remote sensing images, and was considered as the time of tree mortality. CWD with confirmed times of mortality was arranged to a time series. In this way, the change of decomposition rate with time can be calculated by comparing different sample densities.

\section{Experimental methods}

The fresh weight $(\mathrm{M}, \mathrm{g})$ was obtained by weighing a part of the volume of each sample, the dry weight $(\mathrm{m}, \mathrm{g})$ by drying a part of the volume of each sample at $80{ }^{\circ} \mathrm{C}$ for $48 \mathrm{~h}$ to a constant weight. The sample volume $\left(\mathrm{V}, \mathrm{cm}^{3}\right)$ was measured using the displacement method due to the irregular shapes of the samples. CWD water content $\left(W_{\mathrm{CWD}}, \%\right)$ was calculated by subtracting the dry weight from the fresh weight $\left(W_{\mathrm{CWD}}\right.$; Eq. 1), and the sample density ( $\rho$; Eq. 2 ) by dividing the dry weight by the volume.

$W_{\mathrm{cwd}}(\%)=(M-m) / m \times 100 \%$ $\rho\left(\mathrm{g} \mathrm{cm}^{-3}\right)=\mathrm{m} / \mathrm{V}$

The decay rate was estimated based on the changes in density expressed as the decay constant $k$. The year of tree death was assumed to be the same as the year the fires occurred, and a single-exponential decay model ( $k$; Eq. 3) was used to calculate $k$ (Olson 1963). $\mathrm{T}_{0.5}$ and $\mathrm{T}_{0.95}$, representing the decomposition of $50 \%$ and $95 \%$ of the samples, were calculated using Eqs. 4 and 5, respectively (Mackensen and Bauhus 2003):

$k=-\ln \left(X_{\mathrm{t}} / X_{0}\right) / t$

$\mathrm{T}_{0.5}=-\ln (0.5) / k$

$\mathrm{T}_{0.95}=-\ln (0.05) / k$

where $X_{\mathrm{t}}$ is the density at time $t\left(\mathrm{~g} \mathrm{~cm}^{-3}\right), X_{0}$ the initial density of the material $\left(\mathrm{g} \mathrm{cm}^{-3}\right), k$ the decay rate constant, and $t$ the decay time (a).

After measuring the $\mathrm{W}_{\mathrm{CWD}}$ and $\rho$ of each sample, a grinding machine was used to crush the samples, and an EA3000 Elemental Analyzer (EuroVector SRL, Pavia, Italy) used to determine carbon $(\mathrm{Cc}, \%)$ and nitrogen $(\mathrm{Nc}, \%)$ contents to analyze their changes with decomposition and the effect on decay rates. Carbon $\left(\mathrm{C}_{\mathrm{d}}, \mathrm{g} \mathrm{cm}^{-3}\right)$ and nitrogen $\left(\mathrm{N}_{\mathrm{d}}, \mathrm{g} . \mathrm{cm}^{-3}\right)$ densities were obtained by multiplying $\mathrm{C}_{\mathrm{c}}$ and $\mathrm{N}_{\mathrm{c}}$ by the sample density. Using a lignin analyzer for neutral and acid washing, and concentrated sulfuric acid for soaking, lignin $\left(\mathrm{Li}_{\mathrm{c}}\right.$, $\%)$, cellulose $\left(\mathrm{Ce}_{\mathrm{c}}, \%\right)$, and hemicellulose $\left(\mathrm{Hc}_{\mathrm{c}}, \%\right)$ contents were measured (Eqs. 6-8). Lignin $\left(\mathrm{Li}_{\mathrm{d}}, \mathrm{g} \mathrm{cm}^{-3}\right)$, cellulose $\left(\mathrm{Ce}_{\mathrm{d}}, \mathrm{g} \mathrm{cm}^{-3}\right)$, and hemicellulose $\left(\mathrm{Hc}_{\mathrm{d}}, \mathrm{g} \mathrm{cm}^{-3}\right)$ densities were obtained by multiplying the content of these substances by $\rho$.

$\mathrm{Hc}_{\mathrm{c}}(\%)=$ (weight after neutral washing

- weight after acid washing)/

sample weight $* 100$

$\operatorname{Cec}(\%)=($ weight after acid washing - weight after $72 \%$ concentrated sulfuric acid soaking $) /$ sample weight $* 100$

Table 2 Decay classes of coarse woody debris in this study

\begin{tabular}{|c|c|c|c|c|c|}
\hline & I & II & III & IV & V \\
\hline Bark & Complete & Partial shedding & Partial existence & None & None \\
\hline Bole & Solid & Partial decomposition & Partial fragment & Loose inside & Fragment to powder \\
\hline Color & Natural color & Slightly discolored & Light brown & Dark brown & Dark brown \\
\hline Plant & No epiphytes & Some moss & Moss and some seedlings & $\begin{array}{c}\text { Large area with moss and } \\
\text { seedlings, small shrubs }\end{array}$ & $\begin{array}{l}\text { Completely covered with } \\
\text { moss and growing shrubs }\end{array}$ \\
\hline Indirection & Xylem complete & $\begin{array}{l}\text { Blade can be inserted a } \\
\text { few millimeters deep }\end{array}$ & $\begin{array}{l}\text { Blade can be inserted } \\
1-2 \mathrm{~cm} \text { deep }\end{array}$ & $\begin{array}{l}\text { Blade can be inserted } \\
2-5 \mathrm{~cm} \text { deep }\end{array}$ & Blade can be inserted at will \\
\hline
\end{tabular}


Lic $(\%)=($ weight after $72 \%$ concentrated sulfuric acid soaking

- weight after muffle furnace burning) /sample weight $* 100$

To determine the changes in $k, \rho, W_{\mathrm{CWD}}, \mathrm{C}$, and $\mathrm{N}$ turnover, structural components of the debris decomposition process were determined. Ordinary least squares regression and analysis of variance (ANOVA) were used to study the changes in $k, \rho, W_{\mathrm{CWD}}, \mathrm{C}_{\mathrm{c}}, \mathrm{N}_{\mathrm{c}}, \mathrm{C}_{\mathrm{d}}, \mathrm{N}_{\mathrm{d}}, \mathrm{C} / \mathrm{N}, \mathrm{Li}_{\mathrm{c}}, \mathrm{Ce}_{\mathrm{c}}, \mathrm{Hc}_{\mathrm{c}}$, $\mathrm{Li}_{\mathrm{d}}, \mathrm{Ce}_{\mathrm{d}}, \mathrm{Hc}_{\mathrm{d}}$, and lignin/N between different decay classes and to calculate the regression equation of $k$. To explain the effect of $W_{\mathrm{CWD}}, \mathrm{N}_{\mathrm{c}}, \mathrm{C}_{\mathrm{c}}, \mathrm{C} / \mathrm{N}, \mathrm{Li}_{\mathrm{c}}, \mathrm{Ce}_{\mathrm{c}}, \mathrm{Hc}_{\mathrm{c}}, \operatorname{lignin} / \mathrm{N}$, and $\rho$ on $k$, multi-regression equations were established. The log transformation of variables before ordinary least squares regression was used to pass assumptions of normality, linearity, and homoscedasticity of the model. All statistical analyses and charting were carried out in R3.5.1 (2018) software.

\section{Results}

\section{Decay rate $(k)$ based on density change}

The $k, \mathrm{~T}_{0.5}$, and $\mathrm{T}_{0.95}$ values were calculated from Eqs. 3-5 (Table 3). The results show that CWD decomposition was slow in early stages and more rapid in the late stages, and $k$ increases faster in the late decomposition stage. In the entire decomposition process, it took 41 years for $50 \%$ decomposition and 176 years for $95 \%$. The decay rate in each burned patch was positively correlated to decay class, and the rate of increase differed between classes: decay class I was the lowest and decay class IV the highest, with the rate almost doubling. This means that with an increasing number of years after the fire, both the CWD decay class and rate increased.

\section{Factors affecting decay rate (k)}

Univariate regression between $\log (k)$ and $W_{\mathrm{CWD}}, \mathrm{N}_{\mathrm{c}}, \mathrm{C}_{\mathrm{c}}$, $\mathrm{C} / \mathrm{N}, \mathrm{Li}_{\mathrm{c}}, \mathrm{Ce}_{\mathrm{c}}, \mathrm{Hc}_{\mathrm{c}}$, lignin/N, and $\rho$ are shown in Table 4. Most explanatory variables had a significant linear relationship with $\log (k)(P<0.001)$, and the $R^{2}$ values of the linear regression model varied according to the decay class (Table 4). Furthermore, $\rho$ was the most significant factor affecting $k\left(R^{2}=0.294-0.454\right) . R^{2}$ values increased with increasing decay class and significantly affected $k$ in each class. $\log (k)$ was negatively correlated with $\rho$, which indicated that density decreased with ongoing decomposition and $k$ increased accordingly. Decay rate in the early stages (decay class I) was mainly affected by CWD structural components, $\mathrm{Li}_{\mathrm{c}}, \mathrm{Ce}_{\mathrm{c}}$, and $\mathrm{Hc}_{\mathrm{c}}$ (lignin, cellulose
Table 3 Decay rate $(k)$ and time required for $50 \%\left(\mathrm{~T}_{0.5}\right)$ and $95 \%$ $\left(\mathrm{T}_{0.95}\right)$ mass loss of coarse woody debris

\begin{tabular}{|c|c|c|c|c|}
\hline Burn year & Decay class & $K$ & $\mathrm{~T}_{0.5}$ (a) & $\mathrm{T}_{0.95}$ (a) \\
\hline \multirow[t]{4}{*}{1986} & II & 0.012 & 56 & 244 \\
\hline & III & 0.018 & 40 & 171 \\
\hline & IV & 0.023 & 30 & 129 \\
\hline & $\mathrm{V}$ & 0.029 & 24 & 102 \\
\hline \multirow[t]{4}{*}{1987} & II & 0.016 & 43 & 186 \\
\hline & III & 0.020 & 34 & 147 \\
\hline & IV & 0.024 & 29 & 124 \\
\hline & V & 0.027 & 26 & 111 \\
\hline \multirow[t]{5}{*}{2000} & I & 0.012 & 59 & 253 \\
\hline & II & 0.014 & 48 & 207 \\
\hline & III & 0.019 & 36 & 154 \\
\hline & IV & 0.021 & 33 & 142 \\
\hline & $\mathrm{V}$ & 0.027 & 26 & 112 \\
\hline \multirow[t]{5}{*}{2003} & I & 0.012 & 59 & 256 \\
\hline & II & 0.013 & 55 & 238 \\
\hline & III & 0.016 & 45 & 193 \\
\hline & IV & 0.026 & 26 & 114 \\
\hline & V & 0.037 & 19 & 81 \\
\hline \multirow[t]{5}{*}{2009} & I & 0.009 & 81 & 350 \\
\hline & II & 0.012 & 57 & 245 \\
\hline & III & 0.020 & 35 & 152 \\
\hline & IV & 0.027 & 26 & 112 \\
\hline & $\mathrm{V}$ & 0.034 & 20 & 87 \\
\hline \multirow[t]{2}{*}{2010} & I & 0.010 & 72 & 309 \\
\hline & II & 0.015 & 46 & 200 \\
\hline \multirow[t]{2}{*}{2016} & I & 0.009 & 81 & 350 \\
\hline & II & 0.010 & 69 & 297 \\
\hline Mean & & 0.019 & 41 & 176 \\
\hline
\end{tabular}

and hemicellulose) contents. In the middle stages (decay classes II-IV), $\mathrm{C} / \mathrm{N}$ and lignin/ $\mathrm{N}$ significantly affected the rate of decay. The water content $\left(\mathrm{W}_{\mathrm{CWD}}\right)$ influenced the rate of decay in later stages (decay classes IV and V). Carbon levels had no significant effect on $k$. With increasing decay class, factors affecting the decay rate $k$ gradually changed from intrinsic factors $\left(\rho, \mathrm{Li}_{\mathrm{c}}, \mathrm{Ce}_{\mathrm{c}}, \mathrm{Hc}_{\mathrm{c}}, \mathrm{N}_{\mathrm{c}}\right)$ to an environmental factor $\left(\mathrm{W}_{\mathrm{CWD}}\right)$.

To maximize the explanatory ability of the model with few variables, all subsets regression was used to test possible multi-regression models and selected the "best" model (Table 5). Multi-regression analysis could explain the factors that affected $k$ in different decay classes, and all explanatory variables could explain the variance of $\log (k)$ at an average of about $42 \%\left(R^{2}=0.422\right)$. Intrinsic factors $\left(\mathrm{N}_{\mathrm{c}}, \mathrm{C}_{\mathrm{c}}, \rho, \mathrm{Ce}_{\mathrm{c}}\right.$, and $\left.\mathrm{Hc}_{\mathrm{c}}\right)$ had a greater influence on $k$ than the environmental factor $\left(W_{\mathrm{CWD}}\right)$. The multiregression analysis showed that the influencing factors in 
Table 4 Univariate regression results

\begin{tabular}{|c|c|c|c|c|c|}
\hline $\begin{array}{l}\text { Univariate linear } \\
\text { regression model }\end{array}$ & Decay class & Slope & Intercept & $R^{2}$ & $P$ \\
\hline \multirow[t]{3}{*}{$\log (k) \sim \mathrm{W}_{\mathrm{CWD}}$} & IV & 0.003 & -3.891 & 0.023 & $0.032^{*}$ \\
\hline & $\mathrm{V}$ & 0.003 & -3.906 & 0.093 & $0.0005 * * *$ \\
\hline & II & -4.376 & -3.511 & 0.040 & $0.006^{* *}$ \\
\hline \multirow[t]{3}{*}{$\log (k) \sim \mathrm{N}_{\mathrm{c}}$} & III & 6.432 & -5.036 & 0.334 & $7.16 \mathrm{e}-11 * * *$ \\
\hline & IV & 2.043 & -4.108 & 0.052 & $0.001 * *$ \\
\hline & $\mathrm{V}$ & 2.021 & -3.910 & 0.053 & $0.009 * *$ \\
\hline \multirow{2}{*}{$\log (k) \sim \mathrm{C}_{\mathrm{c}}$} & III & 0.117 & -9.993 & 0.073 & $0.005^{* *}$ \\
\hline & II & 0.001 & -4.542 & 0.041 & $0.005 * *$ \\
\hline \multirow[t]{3}{*}{$\log (k) \sim \mathrm{C} / \mathrm{N}$} & III & -0.002 & -3.071 & 0.194 & $2.11 \mathrm{e}-06^{* * *}$ \\
\hline & IV & -0.001 & -3.483 & 0.031 & $0.013^{*}$ \\
\hline & I & 0.070 & -5.615 & 0.140 & $0.001 * *$ \\
\hline \multirow[t]{3}{*}{$\log (k) \sim \mathrm{Li}_{\mathrm{c}}$} & II & 0.047 & -5.286 & 0.063 & $0.0005^{* * *}$ \\
\hline & IV & -0.031 & -2.689 & 0.087 & $2.38 \mathrm{e}-05^{* * *}$ \\
\hline & $\mathrm{V}$ & 0.026 & -4.316 & 0.047 & $0.015^{*}$ \\
\hline \multirow[t]{3}{*}{$\log (k) \sim \mathrm{Ce}_{\mathrm{c}}$} & I & 0.033 & -4.956 & 0.072 & $0.021 *$ \\
\hline & III & -0.053 & -2.319 & 0.149 & $3.94 \mathrm{e}-05^{* * *}$ \\
\hline & I & -0.040 & -3.072 & 0.099 & $0.004 * *$ \\
\hline \multirow[t]{4}{*}{$\log (k) \sim \mathrm{Hc}_{\mathrm{c}}$} & II & 0.069 & -4.819 & 0.046 & $0.003 * *$ \\
\hline & III & -0.120 & -2.787 & 0.096 & $0.001 * *$ \\
\hline & $\mathrm{V}$ & 0.048 & -4.143 & 0.060 & $0.006^{* *}$ \\
\hline & II & 0.002 & -4.575 & 0.067 & $0.0003 * * *$ \\
\hline \multirow[t]{4}{*}{$\log (k) \sim \operatorname{ligin} / \mathrm{N}$} & III & -0.003 & -3.236 & 0.154 & $2.89 \mathrm{e}-05^{* * *}$ \\
\hline & IV & -0.001 & -3.468 & 0.057 & $0.0007 * * *$ \\
\hline & I & -4.836 & -1.277 & 0.294 & $3.56 \mathrm{e}-07 * * *$ \\
\hline & II & -5.340 & -1.449 & 0.308 & $<2.2 \mathrm{e}-16^{* * *}$ \\
\hline \multirow[t]{3}{*}{$\log (k) \sim \rho$} & III & -6.069 & -1.384 & 0.363 & $8.51 \mathrm{e}-13^{* * *}$ \\
\hline & IV & -5.081 & -1.716 & 0.385 & $<2.2 \mathrm{e}-16^{* * *}$ \\
\hline & $\mathrm{V}$ & -7.091 & -1.102 & 0.454 & $<2.2 \mathrm{e}-16^{* * *}$ \\
\hline
\end{tabular}

$k$, decay rate; $\mathrm{W}_{\mathrm{CWD}}$, coarse wood debris water content; $\mathrm{N}_{\mathrm{c}}$, nitrogen content; $\mathrm{C}_{\mathrm{c}}$, carbon content; $\mathrm{Li}$, lignin content; $\mathrm{Ce}_{\mathrm{c}}$, cellulose content; $\mathrm{Hc}_{\mathrm{c}}$, hemicellulose content; $\mathrm{Li}_{\mathrm{d}}$, lignin density; $\mathrm{Ce}_{\mathrm{d}}$, cellulose density; $\mathrm{Hc}_{\mathrm{d}}$, hemicellulose density; $\rho$, coarse wood debris density

$* * * P<0.001 ; * * P<0.01 ; * P<0.05$
Table 5 All-subsets regression results

\begin{tabular}{llll}
\hline All-subsets regression model & Decay class & $\mathrm{R}^{2}$ & $P$ \\
\hline $\log (k)=5.82 \times \mathrm{N}_{\mathrm{c}}-4.9 \times \rho-0.17 \times \mathrm{Hc}_{\mathrm{c}}-1.51$ & $\mathrm{I}$ & 0.382 & $1.049 \mathrm{e}-07^{* * *}$ \\
$\log (k)=0.03 \times \mathrm{C}_{\mathrm{c}}-6.09 \times \rho+0.01 \times \mathrm{W}_{\mathrm{CWD}}-2.8$ & II & 0.375 & $<2.2 \mathrm{e}-16^{* * *}$ \\
$\log (k)=4.64 \times \mathrm{N}_{\mathrm{c}}-3.75 \times \rho-3.03$ & III & 0.435 & $9.391 \mathrm{e}-15^{* * *}$ \\
$\log (k)=0.003 \times \mathrm{W}_{\mathrm{CWD}}-5.35 \times \rho+0.02 \times \mathrm{Ce}_{\mathrm{c}}-2.38$ & IV & 0.434 & $<2.2 \mathrm{e}-16^{* * *}$ \\
$\log (k)=0.04 \times \mathrm{C}_{\mathrm{c}}-6.34 \times \rho+0.002 \times \mathrm{W}_{\mathrm{CWD}}-3.78$ & $\mathrm{~V}$ & 0.484 & $<2.2 \mathrm{e}-16^{* * *}$ \\
\hline
\end{tabular}

$k$, decay rate; $\mathrm{N}_{\mathrm{c}}$, nitrogen content; $\rho$, coarse wood debris density; $\mathrm{Hc}_{\mathrm{c}}$, hemicellulose content; $\mathrm{C}_{\mathrm{c}}$, carbon content; $\mathrm{W}_{\mathrm{CWD}}$, coarse wood debris water content; $\mathrm{Ce}_{\mathrm{c}}$, cellulose content

$* * * P<0.001 ; * * P<0.01 ; * P<0.05$ 
Table 6 Average value of each variable in five decay classes

\begin{tabular}{lrrrrrr}
\hline Variables & \multicolumn{1}{c}{ I } & \multicolumn{1}{c}{ II } & \multicolumn{1}{c}{ III } & \multicolumn{1}{c}{ IV } & \multicolumn{1}{c}{ V } & \multicolumn{1}{c}{ Mean } \\
\hline$k$ & 0.010 & 0.013 & 0.018 & 0.024 & 0.030 & 0.019 \\
$\mathrm{~W}_{\mathrm{CWD}}$ & 24.943 & 22.977 & 34.753 & 53.892 & 122.128 & 51.739 \\
$\mathrm{P}$ & 0.500 & 0.454 & 0.421 & 0.373 & 0.318 & 0.413 \\
$\mathrm{~N}_{\mathrm{c}}$ & 0.093 & 0.103 & 0.145 & 0.186 & 0.197 & 0.145 \\
$\mathrm{C}_{\mathrm{c}}$ & 49.400 & 49.713 & 49.856 & 53.066 & 51.293 & 50.666 \\
$\mathrm{Hc}_{\mathrm{c}}$ & 16.254 & 12.481 & 11.296 & 9.590 & 13.232 & 12.571 \\
$\mathrm{Ce}_{\mathrm{c}}$ & 37.329 & 36.052 & 34.402 & 27.240 & 24.249 & 31.854 \\
$\mathrm{Li}_{\mathrm{c}}$ & 26.767 & 28.174 & 29.420 & 33.046 & 30.869 & 29.655 \\
$\mathrm{~N}_{\mathrm{d}}$ & 0.046 & 0.047 & 0.061 & 0.070 & 0.062 & 0.057 \\
$\mathrm{C}_{\mathrm{d}}$ & 24.683 & 22.577 & 20.981 & 19.815 & 16.294 & 20.870 \\
$\mathrm{Hc}_{\mathrm{d}}$ & 8.121 & 5.668 & 4.754 & 3.581 & 4.203 & 5.266 \\
$\mathrm{Ce}_{\mathrm{d}}$ & 18.651 & 16.373 & 14.478 & 10.171 & 7.703 & 13.475 \\
$\mathrm{Li}_{\mathrm{d}}$ & 13.374 & 12.795 & 12.381 & 12.340 & 9.806 & 12.139 \\
\hline$k, \mathrm{~d}$ & & & & & &
\end{tabular}

$k$, decay rate; $\mathrm{W}_{\mathrm{CWD}}$, coarse wood debris water content; $\rho$, coarse wood debris density; $\mathrm{N}_{\mathrm{c}}$, nitrogen content; $\mathrm{C}_{\mathrm{c}}$, carbon content; $\mathrm{Hc}_{\mathrm{c}}$, hemicellulose content; $\mathrm{Ce}_{\mathrm{c}}$, cellulose content; $\mathrm{Li}_{\mathrm{c}}$, lignin content; $\mathrm{N}_{\mathrm{d}}$, nitrogen density; $\mathrm{C}_{\mathrm{d}}$, carbon density; $\mathrm{Hc}_{\mathrm{d}}$, hemicellulose density; $\mathrm{Ce}_{\mathrm{d}}$, cellulose density; $\mathrm{Li}_{\mathrm{d}}$, lignin density

$* * * P<0.001 ; * * P<0.01 ; * P<0.05$ this study were among many in decomposition that are jointly affected by different explanatory variables at different decomposition stages.

\section{Relationship between decay class and variables}

Average value of each variable in different decay classes

With increasing decay class (I-V), $k, W_{\mathrm{CWD}}, \mathrm{N}_{\mathrm{c}}, \mathrm{N}_{\mathrm{d}}$ increased, $\rho, \mathrm{C}_{\mathrm{d}}, \mathrm{Hc}_{\mathrm{c}}, \mathrm{Ce}_{\mathrm{c}}, \mathrm{Hc}_{\mathrm{d}}, \mathrm{Ce}_{\mathrm{d}}, \mathrm{Li}_{\mathrm{d}}$ decreased (Table 6).
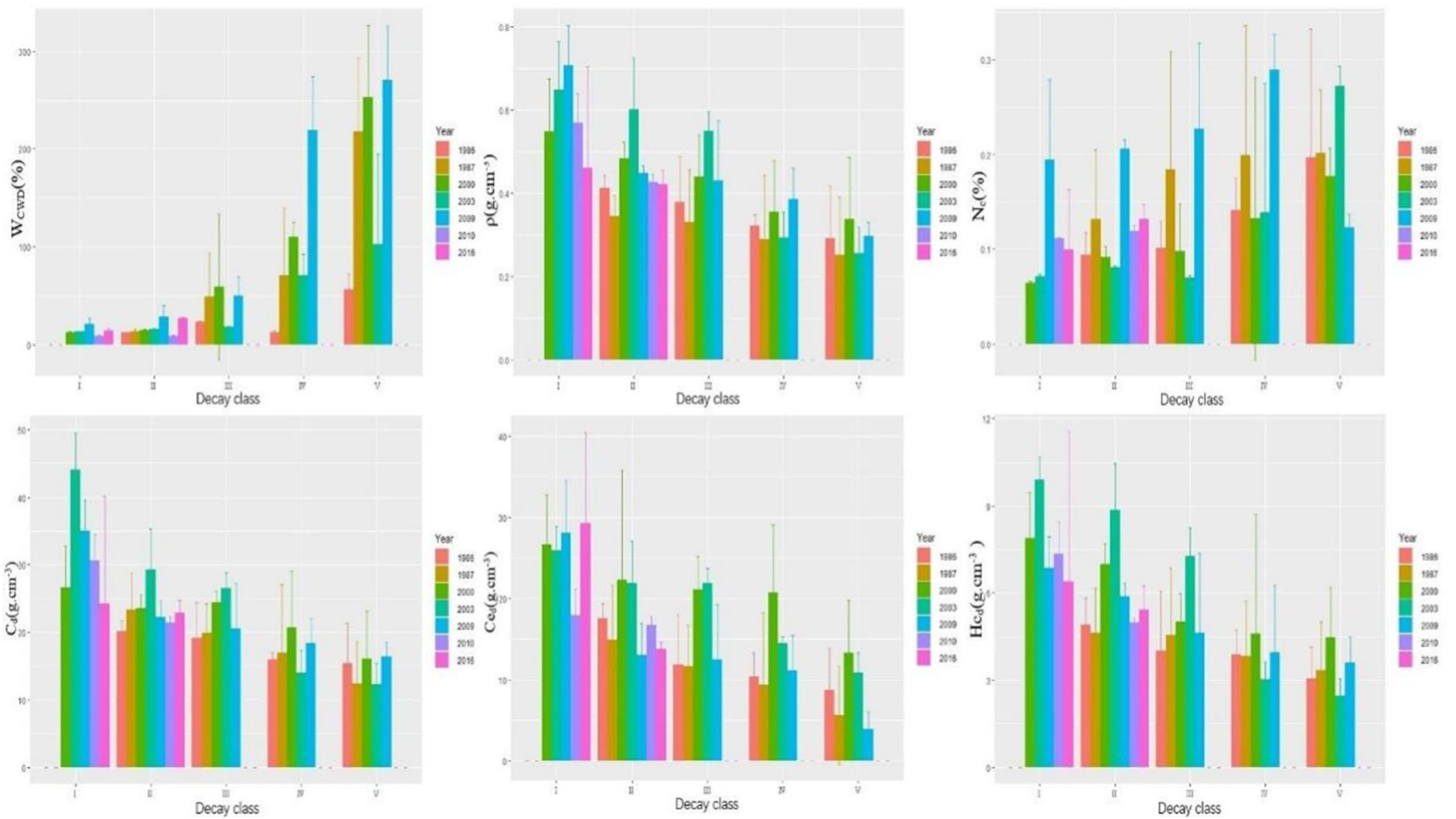

Fig. 3 Average value of variables in five decay classes in different burned patches; $\mathrm{W}_{\mathrm{CWD}}$, coarse wood debris water content; $\rho$, coarse wood debris density; $\mathrm{N}_{\mathrm{c}}$, nitrogen content; $\mathrm{C}_{\mathrm{d}}$, carbon density; $\mathrm{Ce}_{\mathrm{d}}$, cellulose density; $\mathrm{Hc}_{\mathrm{d}}$, hemicellulose density 
However, carbon and lignin contents and nitrogen density $\left(\mathrm{C}_{\mathrm{c}}, \mathrm{Li}_{\mathrm{c}}\right.$ and $\left.\mathrm{N}_{\mathrm{d}}\right)$ increase with an increase of decay class (I-IV), decrease at the fifth decay class but are still greater than in the first four decay classes. Decay rate tripled from decay class I to IV, nitrogen levels increased from 0.09 to $0.20 \%$, average carbon content was about $50 \%$, and carbon density decreased by $34 \%$. The average proportion of CWD structural components was $74 \%$, with cellulose content $\left(\mathrm{Ce}_{\mathrm{c}}\right)$ the highest value, followed by $\mathrm{Li}_{\mathrm{c}}$, and $\mathrm{Hc}_{\mathrm{c}}$ with the lowest. With increasing decay class, the density of lignin, hemicellulose and cellulose $\left(\mathrm{Li}_{\mathrm{d}}, \mathrm{Hc}_{\mathrm{d}}\right.$, and $\left.\mathrm{Ce}_{\mathrm{d}}\right)$ decreased by $26.7 \%$, $48.3 \%$, and $58.7 \%$, respectively. The most readily decomposed variable was cellulose and lignin the least.

Figure 3 shows the variables with the same trend with increasing decay class in different burned patches $\left(W_{\mathrm{CWD}}, \rho\right.$, $\mathrm{N}_{\mathrm{c}}, \mathrm{C}_{\mathrm{d}}, \mathrm{Ce}_{\mathrm{d}}$, and $\left.\mathrm{Hc}_{\mathrm{d}}\right)$. Water content $\left(\mathrm{W}_{\mathrm{CWD}}\right)$ increased significantly in the later stages of decomposition. With increasing decay, nitrogen gradually accumulated and $\mathrm{C}_{\mathrm{d}}, \mathrm{Ce}_{\mathrm{d}}, \mathrm{Hc}_{\mathrm{d}}$, and $\rho$ gradually decreased. Compared with cellulose and hemicellulose contents, their densities changed uniformly between different decay classes, but nitrogen did not, which may be related to low nitrogen levels in coarse woody debris. The inconsistent trend in each variable in the same decay class between the different burned patches reflect the main source of error in the space-time substitution. Conversely, the consistent trend between different decay classes in the same burned patch reflect the influencing factors related to decomposition. The six variables in Fig. 3 are consistent with the variables affecting $k$ in Table 4, which are related to $\mathrm{W}_{\mathrm{CWD}}, \rho, \mathrm{N}, \mathrm{C}, \mathrm{Ce}$, and $\mathrm{Hc}$, indicating that the decay classes provided a standard for the qualitative description of CWD decomposition dynamics. A one-way ANOVA was used to further study the significance of changes in each variable in different decay classes.

\section{Multiple comparison of each variable in different decay classes}

The one-way ANOVA results are shown in Fig. 4. Decay classes are significantly related to values of $\rho, \mathrm{N}_{\mathrm{c}}, \mathrm{C} / \mathrm{N}$, $W_{\mathrm{CWD}}, \mathrm{C}_{\mathrm{d}}, \mathrm{Li}_{\mathrm{d}}, \mathrm{Ce}_{\mathrm{c}}, \mathrm{Hc}_{\mathrm{c}}, \mathrm{Ce}_{\mathrm{d}}$, and $\mathrm{Hc}_{\mathrm{d}}$ indices but were not significant with $\mathrm{N}_{\mathrm{d}}, \mathrm{C}_{\mathrm{c}}, \mathrm{Li}_{\mathrm{c}}$, and lignin/N $(P>0.1)$ and therefore are not described here. The multiple comparison results of $\mathrm{Ce}_{\mathrm{d}}, \mathrm{Hc}_{\mathrm{d}}, \mathrm{C}_{\mathrm{d}}, \rho$, and $\mathrm{W}_{\mathrm{CWD}}$ were more significant. $\mathrm{Ce}_{\mathrm{d}}$, $\mathrm{Hc}_{\mathrm{d}}, \mathrm{C}_{\mathrm{d}}$, and $\rho$ all decreased significantly between the first two decay classes. Compared with decay class $\mathrm{I}, \mathrm{Ce}_{\mathrm{d}}, \mathrm{Hc}_{\mathrm{d}}$, $\mathrm{C}_{\mathrm{d}}$ and $\rho$ decreased significantly in decay class II but not significantly among other classes (II-V). $\mathrm{W}_{\mathrm{CWD}}$ increased from 18 to $113 \%$, almost unchanged in the first three decay classes but was significantly greater in class $\mathrm{V}$ than in the other classes. Nitrogen levels changed smoothly between decay classes and were significantly higher in decay classes
IV and V than in classes I and II, and no significant differences existed between the two adjacent decay classes (I-V). $\mathrm{C} / \mathrm{N}$ ratios decreased with an increase of decay but the fluctuation was not obvious. Adjusted nutrient densities of carbon, lignin, cellulose and hemicellulose $\left(\mathrm{C}_{\mathrm{d}}, \mathrm{Li}_{\mathrm{d}}, \mathrm{Ce}_{\mathrm{d}}\right.$, and $\mathrm{Hc}_{\mathrm{d}}$, in terms of mass loss, showed more significant changes between decay classes than unadjusted nutrient concentrations $\operatorname{did}\left(\mathrm{C}_{\mathrm{c}}, \mathrm{Li}_{\mathrm{c}}, \mathrm{Ce}_{\mathrm{c}}\right.$, and $\left.\mathrm{Hc}_{\mathrm{c}}\right)$.

\section{Discussion}

\section{Previous research on decay rate $(k)$}

Numerous researchers have used single-exponential decay models to calculate the decay rate of coarse woody debris in different regions for different species and have obtained varying results (Table 7). Most studies used space-time substitution, with the time series spanning 13-140 years. Only a few studies have used repeated measurements. Because of the different research methods and areas, $k$ has varied greatly between the research results, and differences between species in the same area reflect the impact of CWD factors on $k$. Mattson et al. (1987) found that $k$ changed 10 times among tree species, and broad-leaved species generally decayed faster than coniferous species. The difference between the same species in different areas reflected the influence of environmental factors on decay rates. In these study, because of the local environment and regional climate, $k$ did not increase with increasing latitude. Repeated measurements could describe $k$ more accurately, and the space-time substitution method could elucidate changes in decay rate over the long term. Nevertheless, some errors did occur.

Compared with the results of repeated measurements, the space-time substitution method underestimated the actual $k$, and the length of the established chronosequence impacted $k$. This study shows that, with increasing decomposition time, $k$ increased with increasing decay class, and the average decay rate in different decomposition periods did not vary substantially. In general, the average $k$-value of $L$. gmelinii coarse woody debris over 33 years was 0.019 , and $50 \%$ and $95 \%$ mass loss occurred over 41 and 176 years, respectively (Table 3). Over 140 years of decomposition, the average decay rate of $L$. gmelinii was $0.013(0.010-0.014), 50 \%$ mass loss took 53 years (50-67 years), and $95 \%$ mass loss took 231 years (219-289 years); the decay rate of snags and logs was not significant ( $\mathrm{Xu}$ 1988). Using the same method of space-time substitution, other researchers obtained $k$ values higher than in this study (Chambers et al. 2001; Mackensen et al. 2003; Lv et al. 2006) and some lower (Chen 

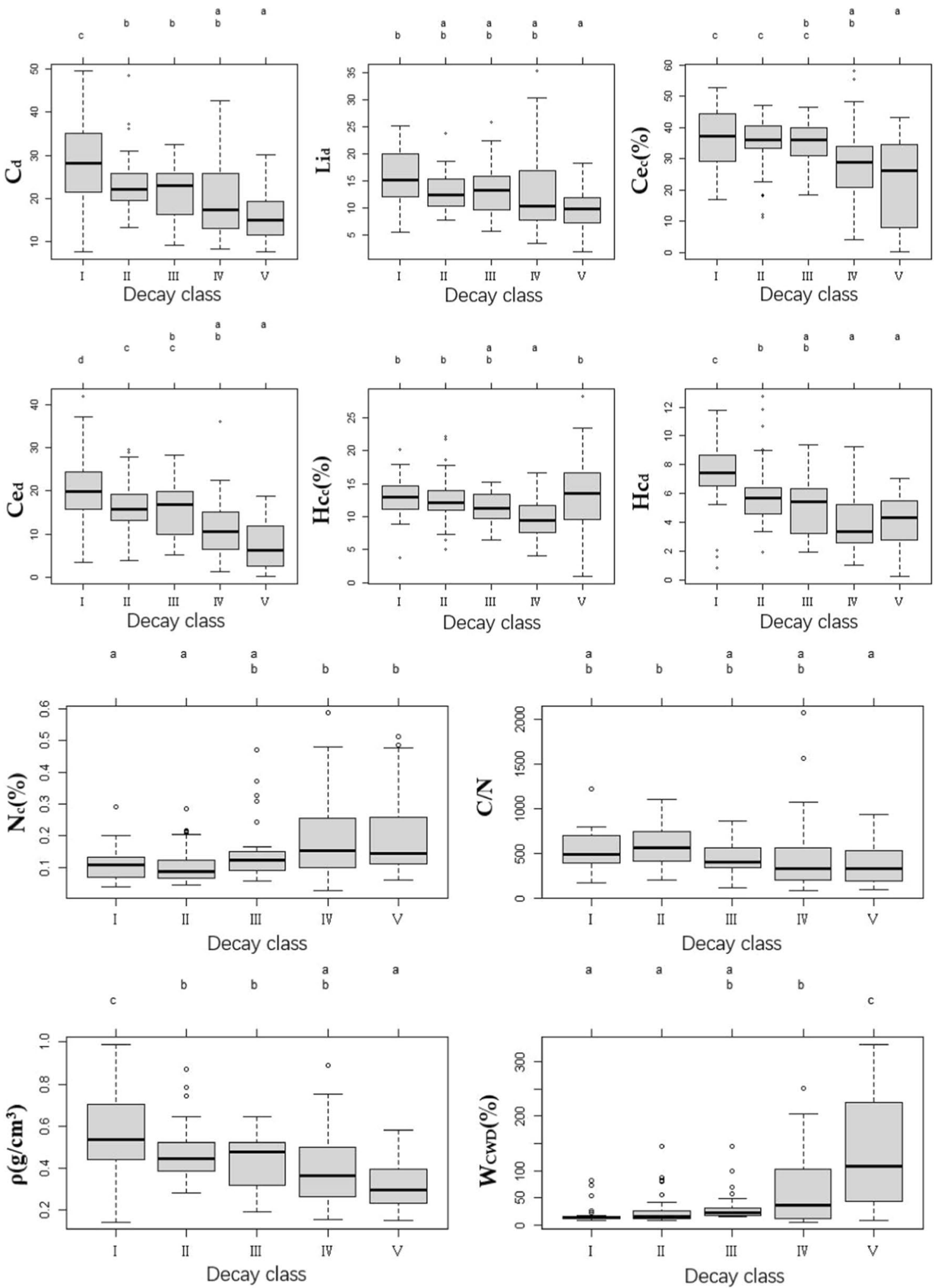

Fig. 4 Multiple comparisons of single factor analysis of variance; same letter between groups show mean difference was insignificant $(P>0.05)$ and letters between groups show that mean difference was significant $(P<0.05) ; \mathrm{C}_{\mathrm{d}}$, carbon density; $\mathrm{Li}_{\mathrm{d}}$, lignin density;

$\mathrm{Ce}_{\mathrm{c}}$, cellulose content; $\mathrm{Ce}_{\mathrm{d}}$, cellulose density; $\mathrm{Hc}_{\mathrm{c}}$, hemicellulose content; $\mathrm{Hc}_{\mathrm{d}}$, hemicellulose density; $\mathrm{N}_{\mathrm{c}}$, nitrogen content; $\rho$, coarse wood debris density; $\mathrm{W}_{\mathrm{CWD}}$, coarse wood debris water content; ***, $P<0.001 ; * *, P<0.01 ; *, P<0.05$ 
Table 7 Decay rate $(k)$ of coarse wood debris

\begin{tabular}{|c|c|c|c|}
\hline Research area & Species & $k$ & Method \\
\hline Northern forest & Pinus sylvestris $L$ & 0.048 & Chronosequence (40 a) \\
\hline of Finland (Shorohova et al. 2008) $\left(61^{\circ} \mathrm{N}, 25^{\circ} \mathrm{E}\right)$ & Picea abies (L.) H. Karst & 0.052 & \\
\hline Northwest Russia (Harmon et al. 2000) & Pinus sylvestris $L$ & 0.015 & Chronosequence \\
\hline \multirow[t]{2}{*}{$\left(59^{\circ} \mathrm{N}, 32^{\circ} \mathrm{E}\right)$} & Picea abies & 0.038 & \\
\hline & Betula pendula Roth & 0.075 & \\
\hline Central Germany (Müller-Using and Bartsch 2009) & Fagus sylvatica $L$ & 0.089 & Chronosequence (28 a) \\
\hline American coniferous & Tsuga heterophylla & 0.036 & Chronosequence (48 a) \\
\hline forest (Janisch et al. 2005) & Pseudotsuga menziesii & 0.015 & \\
\hline American experimental & Tsuga heterophylla & $0.016-0.019$ & \\
\hline forest (Chen and Harmon 1992) & Pseudotsuga menziesii & $0.005-0.010$ & \\
\hline Changbai Mountains (Chen and Harmon 1992) & Tilia amurensis & 0.028 & Chronosequence \\
\hline$\left(42^{\circ} \mathrm{N}, 128^{\circ} \mathrm{E}\right)$ & Pinus koraiensis & 0.016 & \\
\hline Dark coniferous forest in & Abies nephmlepis & 0.017 & Chronosequence \\
\hline the Changbai Mountains (Yang et al. 2002a) & Picea jezoensis & 0.015 & \\
\hline \multirow[t]{4}{*}{ QinLing (Yuan 2016) } & Pinus tabulaeformis & 0.035 & Repeat measurement \\
\hline & Pinus armandi & 0.050 & (4 a) \\
\hline & Larix principis-rupprechtii & 0.032 & \\
\hline & Quercus acutidentata & 0.071 & \\
\hline Japan $\left(34^{\circ} \mathrm{N}, 135^{\circ} \mathrm{E}\right)$ (Jomura et al. 2008) & Pinus densiflora & 0.081 & Repeat measurement (1 a) \\
\hline Liuxi River broad-leaved & Pinus massoniana & $0.057-0.148$ & Repeat measurement ( 1 a) \\
\hline forest $(\mathrm{Ci} 2018)\left(23^{\circ} \mathrm{N}, 113^{\circ} \mathrm{E}\right)$ & Lithocarpus glaber & $0.105-0.160$ & \\
\hline Ailao Mountain (Yang 2007$)\left(23^{\circ} \mathrm{N}, 100^{\circ} \mathrm{E}\right)$ & Average of 4 tree species & 0.019 & Chronosequence (22 a) \\
\hline Dinghu Mountain (Lv et al. 2006) $\left(23^{\circ} \mathrm{N}, 112^{\circ} \mathrm{E}\right)$ & Crptocarya concinna & $0.126-0.223$ & Chronosequence (6 a) \\
\hline Southern Mexico (Eaton and Lawrence 2006) & Average of 4 tree species & 0.278 & Repeat measurement ( $2 \mathrm{a})$ \\
\hline Ecuador (Wilcke et al. 2005) & Tropical mountain evergreen forest & 0.090 & \\
\hline Amazon Basin (Chambers et al. 2001) & Old coniferous forest & 0.130 & \\
\hline Australia (Mackensen and Bauhus 2003) & Pinus radiata & 0.127 & Chronosequence \\
\hline$\left(37^{\circ} \mathrm{S}, 145^{\circ} \mathrm{E}\right)$ & Eucalyptus regnans & 0.041 & \\
\hline$\left(35^{\circ} \mathrm{S}, 150^{\circ} \mathrm{E}\right)$ & Eucalyptus maculata & 0.049 & \\
\hline New Zealand (Ganjegunte et al. 2004) $\left(43^{\circ} \mathrm{S}, 172^{\circ} \mathrm{E}\right)$ & Pinus radiata & 0.074 & Chronosequence (13 a) \\
\hline Greater Khingan Mountains (Xu 1988) & Larix gmelinii & 0.013 & Chronosequence (140 a) \\
\hline Greater Khingan Mountains (Present study) & Larix gmelinii & 0.019 & Chronosequence (33 a) \\
\hline
\end{tabular}

and Harmon 1992; Harmon et al. 2000; Yang et al. 2002) because of different species and locations. The decomposition of L. gmelinii was rapid initially and slower in later stages, which may be related to factors such as the high organic matter of CWD, strong respiration of the material, snags in later decomposition stages in contact with the ground, and changes in temperature and moisture content. Compared with previous studies, the $k$-value of $L$. gmelinii in this study was higher which may be related to the short chronosequence (33 years). Various methods are currently being used to determine the decay rate. In future research, the most appropriate $k$-values need to be used and research methods and contexts need to be considered. Even without information on species and site-specific decay rates, decomposition can be modeled and used to indicate expected decomposition times of individual samples.

\section{Decomposition process}

The decay rate is affected by environmental and intrinsic factors. By establishing regression equations for $k$ (Table 5), the interpretability of each explanatory variable was about $42 \%\left(R^{2}=0.375-0.484\right)$. Moreover, $\rho$ strongly influenced $k\left(R^{2}=0.294-0.454\right)$. In lower decay classes (I-III), structural components (lignin, cellulose and hemicellulose) affected $k$. C/N and lignin/ $\mathrm{N}$ ratios could also be used as indicators of the rate of decomposition. In highly decomposed classes IV and V, a certain degree of fragmentation occurred, and $\mathrm{W}_{\mathrm{CWD}}$ started to affect $k$ (Table 4 ). As decomposition progressed and $k$ increased, the water, lignin and nitrogen contents were positively correlated but levels of cellulose, hemicellulose and density were negatively correlated (Table 6). Structural components as well 
as $\mathrm{C}_{\mathrm{c}}$ and $\mathrm{N}_{\mathrm{c}}$ are related to species, and there are great differences between species. Nitrogen content in CWD varied between species and decay classes $(0.15 \%-0.82 \%)$, and $\mathrm{C} / \mathrm{N}$ ratios showed a decreasing trend with increasing decay class (Noh et al. 2017). For six common species of deciduous temperate forests over 40 months, mass loss was negatively correlated with initial lignin concentration and positively correlated with initial cellulose concentration and density (Cha et al. 2017). Furthermore, decreased lignin concentration increased the $k$.

The water content of coarse woody debris $\left(\mathrm{W}_{\mathrm{CWD}}\right)$ is affected by environmental factors, which in turn affect $k$ by controlling microbial activity. Water makes up $30-160 \%$ of fresh weight, levels which are the most suitable for facilitating microbial growth (Harmon et al. 1986). Research on northern Canadian forest ecosystems found that $\mathrm{W}_{\mathrm{CWD}}$ affected $k$ when the humidity was below $43 \%$, but higher humidities had little effect on decomposition (Chambers et al. 2001). Zell et al. (2009) carried out a meta-analysis of nine European and 30 North American studies from 1973 to 2005 and proposed an equation for an invariant decay constant, indicating that $\mathrm{k}$ was closely related to species, diameter, density, average July temperatures and annual precipitation. The k-value of conifers was 0.63 times higher than that for broad-leaved species and 0.99 times higher than the original value when diameters increased by $10 \mathrm{~cm}$. Mass loss was 1.87 times higher than density loss (impact of fragmentation), and decomposition accelerated with increasing temperature. Rainfall was $1100-1300 \mathrm{~mm}$, and the maximum k occurred at $1226 \mathrm{~mm}$. Mackensen et al. (2003) believed that $k$ reaches a maximum when rainfall range is 1200-1300 mm. Other studies have indicated that large-scale decomposition is related to forest type, days with temperatures exceeding $5{ }^{\circ} \mathrm{C}$, initial decay class, length of coarse debris but not diameter (Russell et al. 2014). The $k$-value is not a constant, and differences in research methods and study areas must be considered before using the estimated $k$-value to compare different forest ecosystems. Among the factors that affect $k$, the existing observation indices are meaningful for understanding the complex decomposition process and for quantifying the influencing factors. Decomposition was defined as the process of carbon release, structural composition loss, and nitrogen accumulation. These observation indexes provide an indirect means of predicting $k$.

The decay classes provided a means of better understanding decomposition. Densities of components $\left(\mathrm{Ce}_{\mathrm{d}}, \mathrm{Hc}_{\mathrm{d}}, \mathrm{C}_{\mathrm{d}}\right)$, and $\rho$ rapidly decreased in the early stages of decomposition, $W_{\mathrm{CWD}}$ increased significantly in the later stages and $\mathrm{N}$ accumulated gradually. With increasing level of decomposition, the $k$-value tripled, $\rho$ decreased from 0.51 to $0.35 \mathrm{~g} /$ $\mathrm{cm}^{3}, W_{\mathrm{CWD}}$ increased from 18 to $113 \%$, and $\mathrm{N}$ increased from 0.093 to $0.197 \%$ (Fig. 4.). In terms of fragmentation, densities $\left(\mathrm{C}_{\mathrm{d}}, \mathrm{Li}_{\mathrm{d}}, \mathrm{Ce}_{\mathrm{d}}\right.$, and $\left.\mathrm{Hc}_{\mathrm{d}}\right)$ changed more significantly between different decomposition stages than the unadjusted concentrations $\left(\mathrm{C}_{\mathrm{c}}, \mathrm{Li}_{\mathrm{c}}, \mathrm{Ce}_{\mathrm{c}}\right.$, and $\left.\mathrm{Hc}_{\mathrm{c}}\right)$ did. Most studies showed that $\mathrm{CWD}$ decomposition consists of $\mathrm{N}$ accumulation and $\mathrm{C}$ release. Thus $\mathrm{C} / \mathrm{N}$ ratios also decreased with ongoing decomposition (Mackensen and Bauhus 2003; Bütler et al. 2007). Some studies have indicated that the nitrogen in woody debris decomposition is related to the decomposition period and tree species. After a 14 year study, Laiho and Prescott (1999) found that the nitrogen content $\left(\mathrm{N}_{\mathrm{c}}\right)$ of Pinus contorta increased with ongoing decomposition. The $\mathrm{N}_{\mathrm{c}}$ in Picea engelmannii was relatively constant, and in Abies lasiocarpa, it decreased.

Harmon et al. (1994) found that N in CWD was released continuously during the first seven years of decomposition; the increased nutrient concentration may have resulted from fungal activity and $\mathrm{N}$ fixation by microorganisms. $\mathrm{N}$ fixation enhances growth and possibly microbial growth in most temperate forest ecosystems (Date 1973). Studies in North America have shown an average nitrogen content in CWD of $0.2-2.1 \mathrm{~kg} \mathrm{ha}^{-1} \mathrm{a}^{-1}$, and could be as high as $5.9 \mathrm{~kg} \mathrm{ha}^{-1}$ $\mathrm{a}^{-1}$ (Harmon et al. 1986). Coarse woody debris can also affect circulation of soil elements by dissolving organic C, resulting in $\mathrm{N}$ fixation (Hafner and Groffman 2005). In USA black pine forests, Busse (1994) found that the proportion of downed logs occupied less than $3 \%$ of the soil nutrient pool and $68 \%$ of the total $\mathrm{C}$ pool, but the estimation of nutrient release from CWD was still limited and the formation mechanism remains unclear.

The present study showed that, with decomposition, nitrogen levels doubled, carbon contents changed by approximately $50 \%$, and structural components changed by about $74 \%$. CWD was not an important source of available $\mathrm{N}$ in the study forest ecosystems. In contrast, the coarse woody debris contributed more to the $\mathrm{C}$ pool and relatively little to nutrient cycling. To date, no consistent conclusion can be drawn about $\mathrm{C}$ and $\mathrm{N}$ turnover in CWD decomposition. Lignin, cellulose and hemicellulose are the main components of plant cell walls, and cellulose is the most easily decomposed, followed by hemicellulose, whereas lignin is the least readily decomposed because of its complex structure (Harmon et al. 1986). In this study, the highest percentage of cellulose was followed by lignin, and hemicellulose was the lowest in CWD, and $\mathrm{Li}_{\mathrm{d}}, \mathrm{Ce}_{\mathrm{d}}, \mathrm{Hc}_{\mathrm{d}}$ decreased by $26.7 \%, 58.7 \%$, and $48.3 \%$, respectively, with increasing decay class, which is consistent with previous research results.

\section{Limitations}

By using a space-time substitution method, the decomposition rate of post-fire Larix gmelini coarse woody debris was estimated and factors affecting it were analyzed. There are some limitations: 
1. This study only estimated the changes of decomposition of coarse woody debris and measured the density, moisture content, structural composition and $\mathrm{C}, \mathrm{N}$ contents, without considering human activities, fire conditions, stand structure, and soil conditions which can affect the decomposition process.

2. A space-time substitution was used to establish a 33 year chronosequence from seven burned patches. The coarse woody debris of Larix gmelini was still in the initial stages of decomposition 33 years after fire, and the number of burned patches needs to be increased to establish a longer chronosequence.

3. An average decomposition rate for debris samples was used to represent an average level in the study forests without considering difference between snags and downed boles. In the future, the decomposition process should be described according to different spatial states of coarse woody debris.

\section{Conclusions}

Wildfires occur frequently in boreal forests and large volumes of coarse woody debris are produced. Quantifying the conversion and decomposition of this material is necessary to clarify the role of boreal forests in carbon cycling. To understand the decomposition process and influencing factors, a single-exponential decay model was used to calculate the k-value of Larix gmelinii.

The average decomposition rate was 0.019 and the average 50\% and 95\% mass loss will take approximately 41 years and 176 years, respectively. The decomposition rate was higher than that of tree species in high northern latitudes. Because of the short chronosequence, the decomposition rate of coarse woody debris of Larix gmelinii was overestimated.

The rate of decomposition increased with decay class. In the lower decay classes, structural components affected decomposition rate, and in the higher decay classes, Water content of the debris had a strong influence on decomposition. Although nitrogen was a small proportion of the debris $(0.093 \%-0.197 \%)$, it had a significant influence on rate of decomposition. With regards to factors that influenced decomposition, each variable could explain about $42 \%$.

ANOVA results showed that the debris rapidly released nutrients in the early stages of decomposition. Nitrogen gradually accumulated and water contents increased rapidly in the later stages of decomposition with the loss of structural components. $\mathrm{C} / \mathrm{N}$ and lignin/ $\mathrm{N}$ ratios were indicators of decomposition rate but they were not sufficient to distinguish decay classes.

This study provides a new perspective to quantify the interaction between energy flow in coarse woody debris and nitrogen cycling, and provides a deeper understanding of the decomposition process. However, more research is needed to calculate decomposition rates accurately and to analyze environmental factors that affect the decomposition process.

Open Access This article is licensed under a Creative Commons Attribution 4.0 International License, which permits use, sharing, adaptation, distribution and reproduction in any medium or format, as long as you give appropriate credit to the original author(s) and the source, provide a link to the Creative Commons licence, and indicate if changes were made. The images or other third party material in this article are included in the article's Creative Commons licence, unless indicated otherwise in a credit line to the material. If material is not included in the article's Creative Commons licence and your intended use is not permitted by statutory regulation or exceeds the permitted use, you will need to obtain permission directly from the copyright holder. To view a copy of this licence, visit http://creativecommons.org/licenses/by/4.0/.

\section{References}

Amiro BD, Orchansky AL, Barr AG, Black TA, Chambers SD, Chapin Iii FS, Goulden ML, Litvak M, Liu HP, McCaughey JH, McMillan A, Randerson JT (2006) The effect of post-fire stand age on the boreal forest energy balance. Agric For Meteorol 140:41-50

Attiwill P (1994) The disturbance of forest ecosystems: the ecological basis for conservative management. For Ecol Manag 63:247-300

Busse M (1994) Downed bole-wood decomposition in lodgepole pine forests of central Oregon. Soil Sci Soc Am J 58:221-227

Bütler R, Patty L, Le Bayon RC, Guenat C, Schlaepfer R (2007) Log decay of Picea abies in the Swiss Jura Mountains of central Europe. For Ecol Manag 242:791-799

Carmona M, Armesto JJ, Aravena J, Pérez C (2002) Coarse woody debris biomass in successional and primary temperate forests in Chiloé Island, Chile. For Ecol Manag 164:265-275

Catry F, Rego F, Moreira F, Fernandes P, Pausas JG (2010) Post-fire tree mortality in mixed forests of central Portugal. For Ecol Manage 260:1184-1192

Catry F, Pausas J, Moreira F, Fernandes P, Rego F (2013) Post-fire response variability in Mediterranean basin tree species in Portugal. Int J Wildland Fire 22:919-932

Cha S, Chae HM, Lee SH, Shim JK (2017) Branch wood decomposition of tree species in a deciduous temperate forest in Korea. Forests 8:176

Chambers J, Schimel J, Nobre A (2001) Respiration from coarse wood litter in central Amazon forests. Biogeochemistry 52:115-131

Chen H, Harmon ME (1992) Dynamic study of coarse woody debris in temperate forest ecosystems. Chin J Appl Ecol 2:99-104

Ci H (2018) Characteristics of coarse woody debris decomposition and respiration of two tree species at Liuxihe. Chinese Academy of Forestry, Beijing, pp 5-15

Currie W, Nadelhoffer K (2002) The imprint of land-use history: patterns of carbon and nitrogen in downed woody bebris at the Harvard forest. Ecosystems 5:446-460

Date RA (1973) Nitrogen, a major limitation in the productivity of natural communities, crops and pastures in the Pacific area. Soil Biol Biochem 5:5-18

Delaney M, Brown S, Lugo AE, Torres-Lezama A, Quintero NB (1998) The quantity and turnover of dead wood in permanent forest plots in six life zones of Venezuela. Biotropica 30:2-11

Eaton J, Lawrence D (2006) Woody debris stocks and fluxes during succession in a dry tropical forest. For Ecol Manag 232:46-55 
Fernandes P, Vega J, Jiménez E, Rigolot E (2008) Fire resistance of European pines. For Ecol Manag 256:246-255

Fogel R, Cromack K (2011) Effect of habitat and substrate quality on Douglas fir litter decomposition in western Oregon. Can J Bot 55:1632-1640

Frangi JL, Richter LL, Barrera MD, Aloggia M (1997) Decomposition of Nothofagus fallen woody debris in forests of Tierra del Fuego, Argentina. Can J For Res 27:1095-1102

Ganjegunte GK, Condron LM, Clinton PW, Davis MR, Mahieu $\mathrm{N}$ (2004) Decomposition and nutrient release from radiata pine (Pinus radiata) coarse woody debris. For Ecol Manag 187:197-211

Guo FT (2007) Estimated gas emission from forest fire in Daxing'an Mountain. Northest Forestry University, Harbin, pp 1-12

Guo M, Li J, Huang SB, Wen LX (2020) Feasibility of using MODIS products to simulate sun-Induced chlorophyll fluorescence (SIF) in boreal forests. Remote Sens 12:3-8

Hafner SD, Groffman PM (2005) Soil nitrogen cycling under litter and coarse woody debris in a mixed forest in New York State. Soil Biol Biochem 37:2159-2162

Harmon ME, Franklin JF, Swanson FJ, Sollins P, Gregory SV, Lattin JD, Anderson NH, Cline SP, Aumen NG, Sedell JR, Lienkaemper GW, Cromack K, Cummins KW (1986) Ecology of coarse woody debris in temperate ecosystems. Ad Ecol Res 15:133-302

Harmon ME, Sexton J, Caldwell BA, Carpenter SE (1994) Fungal sporocarp mediated losses of $\mathrm{Ca}, \mathrm{Fe}, \mathrm{K}, \mathrm{Mg}, \mathrm{Mn}, \mathrm{N}, \mathrm{P}$, and $\mathrm{Zn}$ from conifer logs in the early stages of decomposition. Can J For Res 24:1883-1893

Harmon ME, Krankina O, Sexton J (2000) Decomposition vectors: a new approach to estimating woody detritus decomposition dynamics. Can J For Res 30:76-84

Hayes DJ, McGuire AD, Kicklighter DW, Gurney KR, Burnside TJ, Melillo JM (2011) Is the northern high-latitude land-based $\mathrm{CO}_{2}$ sink weakening? Glob Biogeochem Cycles 25:1-11

Hu YM, Xu CG, Chang Y, Li XZ, Bu RC, He HS, Leng WF (2004) Application of spatially explicit landscape model (LANDIS): a case researches in Huzhong area. Mt Daxing 'anling Acta Ecologica Sinica 24:1846-1856

Janisch J, Harmon ME, Chen H, Fasth B, Sexton J (2005) Decomposition of coarse woody debris originating by clearcutting of an old-growth conifer forest. Ecoscience 12:151-160

Jomura M, Kominami Y, Dannoura M, Kanazawa Y (2008) Spatial variation in respiration from coarse woody debris in a temperate secondary broad-leaved forest in Japan. For Ecol Manag 255:149-155

Kruys N, Jonsson B, Stahl G (2002) A stage-based matrix model for decay-class dynamics of woody debris. Ecol Appl 12:773-781

Laiho R, Prescott C (1999) The contribution of coarse woody debris to carbon, nitrogen, and phosphorous cycles in three Rocky Mountain coniferous forests. Can J For Res 29:1592-1603

Lierop P, Lindquist E, Sathyapala S, Franceschini G (2015) Global forest area disturbance from fire, insect pests, diseases and severe weather events. For Ecol Manag 352:78-88

Liu ZX, Zhang L, Ou YD, Sun D, Su ZY (2011) The composition and structure of coarse woody debris in the evergreen broadleaved forest after ice storm in northern Guangdong province. J Southwest For Univ 31:18-23

Lorimer C (2011) Methodological consideration in the analysis of forest disturbance history. Can J For Res 15:200-213

Lv MH, Zhou GY, Zhang DQ (2006) Decomposition of Cryptocarya concinna coarse woody debris (CWD) in Dinghushan. Guihaia 26:523-529

Mackensen J, Bauhus J (2003) Density loss and respiration rates in coarse woody debris of Pinus radiata, Eucalyptus regnans and Eucalyptus maculata. Soil Biol Biochem 35:177-186
Mackensen J, Bauhus J, Webber E (2003) Decomposition rates of coarse woody debris-A review with particular emphasis on Australian tree species. Aust J Bot 51:27-37

Marra J, Edmonds R (1994) Coarse woody debris and forest floor respiration in an old-growth coniferous forest on the Olympic Peninsula, Washington, USA. Can J For Res 24:1811-1817

Mattson KG, Swank WT, Waide JB (1987) Decomposition of woody debris in a regenerating, clear-cut forest in the Southern Appalachians. Can J For Res 17:712-721

McLauchlan KK, Higuera PE, Miesel J, Rogers BM, Schweitzer J, Shuman JK, Tepley AJ, Varner JM, Veblen TT, Adalsteinsson SA, Balch JK, Baker P, Batllori E, Bigio E, Brando P, Cattau M, Chipman ML, Coen J, Crandall R, Daniels L, Enright N, Gross WS, Harvey BJ, Hatten JA, Hermann S, Hewitt RE, Kobziar LN, Landesmann JB, Loranty MM, Maezumi SY, Mearns L, Moritz M, Myers JA, Pausas JG, Pellegrini AFA, Platt WJ, Roozeboom J, Safford H, Santos F, Scheller RM, Sherriff RL, Smith KG, Smith MD, Watts AC, Durigan G (2020) Fire as a fundamental ecological process: research advances and frontiers. J Ecol 108:20147-22069

Montes F, Cañellas I (2006) Modelling coarse woody debris dynamics in even-aged Scots pine forests. For Ecol Manag 221:220-232

Motta R, Berretti R, Lingua E, Piussi P (2006) Coarse woody debris, forest structure and regeneration in the Valbona Forest Reserve, Paneveggio, Italian Alps. For Ecol Manag 235:155-163

Müller-Using S, Bartsch N (2009) Decay dynamic of coarse and fine woody debris of a beech (Fagus sylvatica L.) forest in Central Germany. Eur J Forest Res 128:287-296

Noh N, Yoon T, Kim RH, Bolton N, Kim C, Son Y (2017) Carbon and nitrogen accumulation and decomposition from coarse woody debris in a naturally regenerated Korean red pine (Pinus densiflora S. Et Z.) forest. Forests 8:214

Olson JS (1963) Energy storage and the balance of producers and decomposers in ecological systems. Ecology 44:322-325

Russell M, Woodall C, D'Amato A, Fraver S, Bradford J (2014) Technical Note: linking climate change and downed woody debris decomposition across forests of the eastern United States. Biogeosciences 11:6417-6425

Shorohova E, Kapitsa E, Vanha-Majamaa I (2008) Decomposition of stumps in a chronosequence after clear-felling vs. clear-felling with prescribed burning in a southern boreal forest in Finland. For Ecol Manag 255:3606-3612

Sollins P (1982) Input and decay of coarse woody debris in coniferous stands in western Oregon and Washington. Can J For Res 12:18-28

Spies TA, Franklin JF, Thomas TB (1988) Coarse woody debris in Douglas-fir forests of western Oregon and Washington. Ecology 69:1689-1702

Sturtevant B, Bissonette J, Long J, Roberts D (1997) Coarse woody debris as a function of age, stand structure, and disturbance in boreal Newfoundland. Ecol Appl 7:702-712

Tang XL, Zhou GL, Zhou X, Wen DZ, Zhang QM, Yin GC (2003) Coarse woody debris in monsoon evergreen broad-leaved forests of Dinghushan nature reserve. Acta Phytoecol Sin 27:484-489

Tyrrell L, Crow T (1994) Dynamics of in old-growth hemlock-hardwood forests of northern Wisconsin and northern Michigan. Can J For Res 24:1672-1683

Wang CK, Gower ST, Wang YH, Zhao HX, Yan P, Bond-Lamberty BP (2001) The influence of fire on carbon distribution and net primary production of boreal Larix gmelinii forests in north-eastern China. Glob Change Biol 7:719-730

Weedon J, Cornwell W, Cornelissen J, Zanne A, Wirth C, Coomes D (2008) Global meta-analysis of wood decomposition rates: a role for trait variation among tree species? Ecol Lett 12:45-56 
Wilcke W, Hess T, Bengel C, Homeier J, Valarezo C, Zech W (2005) Coarse woody debris in a montane forest in Ecuador: mass, C and nutrient stock, and turnover. For Ecol Manag 205:139-147

Wu JB, Guan DX, Han SJ, Zhang M, Jin CJ (2005) Ecological functions of coarse woody debris in forest ecosystem. J For Res $16: 247-252$

Wu ZW, He HS, Liu XM, Wu ZF, Yu L, Zhang PF, Li SH, Song GH, Wang QB (2011) Study on coarse woody debris in broadleaved Korean pine forest of Fenglin National natural reserve. Ecol Sci 30:150-155

Xu HC (1988) Da hinggin ling mountains forest in China. Science Press, Beijing, pp 30-55

Xu WR (2018) Effects of commercial harvest exclusion on forest composition, structure and spatial distribution of the Great Xing' an Mountains. Northeast Normal University, Changchun, pp 20-28

Yang LP (2007) Biomass, composition and ecological functions of woody debris in montane moist evergreen broard-leaved forest in Ailao. Graduate School of the Chinese Academy of Sciences (Xishuangbanna Tropical Botanical Garden), Beijing, pp 10-15

Yang LY, Dai LM, Zhang YJ (2002) Storage and decomposition of fallen wood in dark coniferous forest on the north slope of Changbai Mountain. J Appl Ecol 13:1069-1071

Yatskov M, Harmon ME, Krankina O (2003) A chronosequence of wood decomposition in the boreal forests of Russia. Can J For Res 33:1211-1226

Yuan J (2016) Coarse woody debris of main forest types at Huoditang forest region in the QinLing Mountains. Northwest Agriculture \& Forestry University, Xianyang, pp 15-20

Yuan J, Hou L, Zhang SX (2011) Research progress in coarse woody debris. J Northwest For Univ 26:90-98
Yuan J, Cai J, Hou L, Zhang SX (2012) Storage and decomposition of fallen wood in a Pinus tabulaeformis secondary forest at Huoditang forest region in the Qinling mountains. Scientia Silvae Sinicae 48:141-146

Yue C, Ciais P, Cadule P, Thonicke K, Leeuwen T (2015) Modelling the role of fires in the terrestrial carbon balance by incorporating SPITFIRE into the global vegetation model ORCHIDEE-Part 2: carbon emissions and the role of fires in the global carbon balance. Geosci Model Dev 8:1321-1338

Zell J, Kändler G, Hanewinkel M (2009) Predicting constant decay rates of coarse woody debris-A meta analysis approach with a mixed model. Ecol Model 220:904-912

Zhang LM, Wang CK (2010) Carbon and nitrogen release during decomposition of coarse woody debris for eleven temperate tree species in the eastern mountain region of northeast China. Chin J Plant Ecol 34:368-374

Zhang XY, Guan DS, Zhang HD (2009) Characteristics of storage and decomposition of coarse woody debris (CWD) under three forests in Guangzhou. Acta Ecol Sin 09:5227-5236

Zhu JX, Zhou XL, Fang WJ, Xiong XY, Zhu B, Ji CJ, Fang JY (2017) Plant debris and its contribution to ecosystem carbon storage in successional Larix gmelinii forests in northeastern China. Forests $8: 191$

Publisher's Note Springer Nature remains neutral with regard to jurisdictional claims in published maps and institutional affiliations. 